Article

\title{
The Variable Influences of Sea Level, Sedimentation and Exposure on Holocene Reef Development over a Cross-Shelf Transect, Central Great Barrier Reef
}

\author{
Emma J. Ryan ${ }^{1,2}, * \mathbb{0}$, Scott G. Smithers ${ }^{2}$, Stephen E. Lewis ${ }^{3}{ }^{-0}$, Tara R. Clark ${ }^{4,5}$ \\ and Jian-xin Zhao ${ }^{4}$ \\ 1 School of Environment, The University of Auckland, Auckland 1010, New Zealand \\ 2 Environmental Science and Management, College of Science and Engineering, James Cook University, \\ Townsville 4811, Australia; scott.smithers@jcu.edu.au \\ 3 TropWATER, James Cook University, Townsville 4811, Australia; stephen.lewis@jcu.edu.au \\ 4 Radiogenic Isotope Facility, School of Earth and Environmental Science, The University of Queensland, \\ Brisbane 4072, Australia; t.clark1@uq.edu.au (T.R.C.); j.zhao@uq.edu.au (J.-x.Z.) \\ 5 Australian Research Centre for Human Evolution, Environmental Futures Research Institute, \\ Griffith University, Nathan 4111, Australia \\ * Correspondence: e.ryan@auckland.ac.nz; Tel.: +64-9-373-7599
}

Received: 5 August 2018; Accepted: 4 October 2018; Published: 11 October 2018

check for updates

\begin{abstract}
Coral reefs globally are impacted by natural and anthropogenic stressors that are compounded by climate change. Understanding past reef responses to natural stressors (cyclones, sea-level change, freshwater inputs, and sedimentation) can provide important insights to further understand recent (within the past century) trends in coral cover and diversity. Here we use a compilation of recently published data to investigate the Holocene development of five fringing reefs that are located on a cross-shelf transect on the central Great Barrier Reef, and that are exposed to varying degrees of natural and anthropogenic sedimentation, storm exposure, and Holocene sea-level change. Forty-two reef cores collected using a combination of manual percussion coring and hydraulic drilling techniques, were analysed and dated using uranium-thorium methods. The chronostratigraphic records of reef development established using 105 recently published radiometric ages and seven new uranium-thorium ages from the reef cores and fossil microatolls preserved across the reef flats were compared to investigate cross-shelf variations in reef development. This is the first study to conduct an internal investigation of reef framework across an inshore-offshore gradient to examine the varying levels of influence of sedimentation, sea level and cyclones. Our observations from the central Great Barrier Reef show that reefs furthest offshore from the mainland coast were typically initiated earliest after the post-glacial marine transgression. Reef flat size, morphology, and growth style varied according to constraints placed on reef development by the composition, depth, shape, and relief of the underlying substrate. We establish that terrigenous sedimentation had a marked effect on the development of inshore reefs closest to the mainland (within $10 \mathrm{~km}$ of the mainland coast). Periods of relatively high terrigenous sedimentation correspond with enhanced reef accretion rates, and also resulted in a superior record of palaeo-ecological coral composition (i.e., better preservation) at inshore sites. In contrast, mid-Holocene cyclones played a seemingly more important role in the development of reefs $>10 \mathrm{~km}$ from the mainland; although cyclones clearly affect reefs closer inshore, their geomorphology is affected by a range of controlling factors. Insights provided by these five Holocene reef chronostratigraphies provide useful baseline understanding of reef condition and growth along a cross-shelf transect where the reefs are exposed to variable stressors.
\end{abstract}

Keywords: Great Barrier Reef; chronostratigraphy; Holocene; reef development; sedimentation; cyclone; U-Th dating; cross-shelf 


\section{Introduction}

Tropical coral reefs are threatened by a range of natural impacts (tropical cyclones [1], sedimentation [2], sea-level change, and elevated sea surface temperature), which are compounded by anthropogenic stressors, such as global climate change effects [3], over-fishing [4], enhanced nutrients and sediments [5]. Such natural and anthropogenic stressors have been reported as causing major declines in coral cover and composition on Australia's Great Barrier Reef (GBR) over the past few decades [6-8]. However, isolating natural effects from anthropogenic effects on coral reefs is difficult due to the paucity of data on baseline reef condition and underlying temporal and spatial variability of natural stressors. Indeed, modern ecological datasets span a very short time period (usually 20 to 40 years) relative to the time period over which anthropogenic pressures might have been exerted ( 150 years) and the timeframe preserved in reef structures and captured in reef cores, which can include several millennia. Long-term (millennial-scale) insights into past reef development, including palaeo-ecology, provide baseline context that can help to assess whether recent documented changes in reef condition are unprecedented [9] and support efforts to isolate the relative importance of various reported stressors to coral reefs $[10,11]$ to inform future reef management [12].

Long-term records of reef development can be derived from radiometrically dated reef cores, which reveal important insights on reef initiation, the timing, mode and rates of reef development, reef palaeo-ecology, sediment regimes, and variations in those factors through time [13,14]. Investigations of Holocene reef development on the GBR largely began in the 1970s using isolated boreholes and reef cores, confirming the depth and age of the Holocene-Pleistocene reef boundary $[15,16]$. Various drilling expeditions were then carried out in the 1980s, which greatly expanded the dataset of reef cores, allowing for a more detailed exploration of how and when the reefs of the GBR developed [17-21], including in response to environmental drivers such as sea-level changes. The focus of these investigations were the barrier reefs of the outer GBR shelf (beyond the $50 \mathrm{~m}$ isobath), however several fringing reefs on the inner- (within the $20 \mathrm{~m}$ isobath) and mid-shelf (20-50 m isobaths) were also investigated. These early chronostratigraphic investigations confirmed that many modern reefs of the GBR began to develop around $8000-7000 \mathrm{yBP}$ as the post-glacial marine transgression (PGMT) flooded the inner GBR shelf and the reefs grew in 'keep-up' or 'catch-up' mode to reach sea level and subsequently prograded seaward through the mid-Holocene to form reef flats. It is now accepted that sea level on the GBR approached the present position around $7000 \mathrm{yBP}$ before reaching a mid-Holocene highstand of 1.0-1.5 m above present [22]. The details of sea-level history post highstand are contentious, with various researchers contending that it fell to the present level either slowly and smoothly [23,24], rapidly in the late-Holocene after a more prolonged highstand [25], or gradually in an oscillating manner [26,27]. Despite these uncertainties, many reef flats on the inner GBR were formed during the sea-level highstand at elevations above modern reef flat development. These reef flats are now exposed at low tidal stages due to the subsequent relative sea-level fall. In the past few decades, investigations of Holocene reef development on the GBR have increased in number and become more detailed, as the value of long-term records is increasingly recognised, and advancements in coring and dating techniques improve data quality (see reviews in 5,7). In particular, investigations on inshore reefs located within $20 \mathrm{~km}$ from the mainland coast have increased due to their perceived vulnerability to anthropogenic stressors [28-31].

Since European settlement of the Queensland coast in the 1850s, sediment and nutrient loads exported to the inshore GBR have increased two- to 10-fold [32-34], generating concern for the health of inshore fringing reefs. Coral cover and diversity on the GBR have been shown to decline along a gradient of increasing suspended sediment and nutrients in the water column [7,35]. Nevertheless, many inshore reefs on the GBR have developed close to the coast in naturally turbid settings [36] and continue to display relatively high coral cover (up to 50\% live coral cover), diversity [37-39] 
and accretion rates (averaging up to $13 \mathrm{~mm} / \mathrm{yr}$ ) [29,40,41] compared to their offshore counterparts. These recent data highlight the ability of inshore reefs to flourish in conditions that are generally considered unfavorable for reef health $[28,31,38]$ and they demonstrate that not all inshore reefs can be considered degraded.

Spatial variations in baseline reef condition (and variations across the GBR shelf) must be understood to better resolve the impacts of natural stressors on reefs and to help to differentiate the effects of anthropogenic stressors. Very few published studies have explored the internal reef structure and Holocene reef development across the GBR shelf from inshore to offshore [18,42,43]. This study aims to use previously published reef cores and radiometric ages in $[39,44-46]$ to present the first detailed comparison of cross-shelf variations in Holocene fringing reef growth characteristics (i.e., antecedent substrates, timing and depth of reef initiation, timing and rates of reef accretion, and palaeo-ecology) on the central GBR. The cross-shelf transect extends $40 \mathrm{~km}$ offshore from the mainland to the mid-shelf in the central GBR, allowing a gradient of anthropogenic influence and exposure to be investigated. We show that reefs located close to the mainland coast are typically younger, shallower, and exhibit wider reef flats than their offshore counterparts. Terrigenous sedimentation had a marked effect on the timing, rate and type of reef development at those inshore reefs closest to the mainland (within $10 \mathrm{~km}$ of the mainland coast), while cyclones played a more important role in the geomorphological development of reefs further offshore.

\section{Materials and Methods}

The Holocene accretion histories of five fringing reefs on Australia's central GBR were examined (Figure 1). The five study sites include fringing reefs located in diverse environmental settings: mainland-attached (Bramston Reef, $148^{\circ} 15^{\prime} \mathrm{E}, 20^{\circ} 03^{\prime} \mathrm{S}$ ), within an island embayment (Stone Island North [SI-N], $148^{\circ} 17^{\prime} \mathrm{E}, 20^{\circ} 02^{\prime} \mathrm{S}$ ), and attached to headlands/shorelines of offshore islands located between 3 and $40 \mathrm{~km}$ from the mainland (Stone Island South (SI-S), $148^{\circ} 17^{\prime} \mathrm{E}, 20^{\circ} 02^{\prime} \mathrm{S}$, Middle Island, $148^{\circ} 22^{\prime} \mathrm{E}, 19^{\circ} 59^{\prime} \mathrm{S}$ and Holbourne Island, $148^{\circ} 21^{\prime} \mathrm{E}, 19^{\circ} 43^{\prime} \mathrm{S}$ ). The study sites are located along a cross-shelf transect extending from the mainland coast in Edgecumbe Bay, across the inner-shelf to the mid-shelf, $40 \mathrm{~km}$ offshore. This transect captures a gradient of terrestrial and direct anthropogenic influences that diminish with distance from the mainland and from river mouths, over which cross-shelf variations in reef development can be examined. Variations in exposure to natural disturbances may also occur across the GBR shelf, including: greater re-suspension of the terrigenous sediment wedge [47] and greater hydro-isostacy effects [48] in inshore areas, and greater exposure to physical effects of tropical cyclones further offshore.

At all sites, the reef flat surface was exposed during low tidal stages and groups of well-preserved fossil coral microatolls were found on the reef flats. Microatolls are discoid coral colonies with living polyps around their vertical edges and mostly dead flat upper surfaces, developed by the coral in response to prolonged subaerial exposure at low tide [49]. Thus, microatoll formation is limited to intertidal zones on reef flat surfaces. The minimum age for reef flat formation can be approximated using dated open-water fossil microatolls [24].

This manuscript presents a compilation of precisely dated, recently published $[39,44-46]$ records of Holocene reef development based on the internal reef structure derived from manual percussion cores $(n=37)$ and hydraulic drill cores $(n=5)$ driven vertically into the reef flat at five fringing reefs on the central GBR (Table S1). Cores were evenly spaced along a transect that extended from the shoreline across each reef flat to the reef edge (Figure 1). The 42 reef cores extended between 1.2 and $8.0 \mathrm{~m}$ below the reef flat surfaces and captured the majority of Holocene reef growth at all sites. Chronostratigraphic records of Holocene reef growth, palaeo-coral diversity and sediment regimes were developed using a total of 112 radiometric ages (105 of these ages have been recently published, while seven were first published within this manuscript; see Table S2) of well-preserved in situ corals selected within the cores and samples from Porites fossil microatolls on the reef flat surface (Table S2) in conjunction with detailed core logs and analyses of core matrix sediment size (through 
settling techniques) and carbonate content (through acid digestion). Detailed methodologies of core retrieval, core logging, analyses of core matrix sediment size, and carbonate content and taxonomy and U-Th dating of well-preserved in situ coral material are presented in [39,43-46]. A total of 43 fossil microatolls were sampled across the five sites by taking small cores of coral skeleton $(3.0 \mathrm{~cm}$ in length and $2.5 \mathrm{~cm}$ in diameter) from the surface outer edge of each fossil microatoll. The age of each colony was determined using either U-Th dating using a Nu Plasma I multi-collector inductively coupled plasma mass-spectrometer, following the techniques described in [39,50-52], or radiocarbon dating by accelerator mass spectrometry, as described and presented in [46]. Many of these fossil microatoll ages contributed to reconstructions of reef development. The previously published data from Bramston Reef [39], Stone Island [45], Middle Island [44], and Holbourne Island [46] are combined in this manuscript to explore temporal and spatial variations in the timing and nature of reef growth, core matrix sediments, and coral assemblages between the five sites to differentiate drivers of past changes in reef evolution and to synthesise cross-shelf variations.
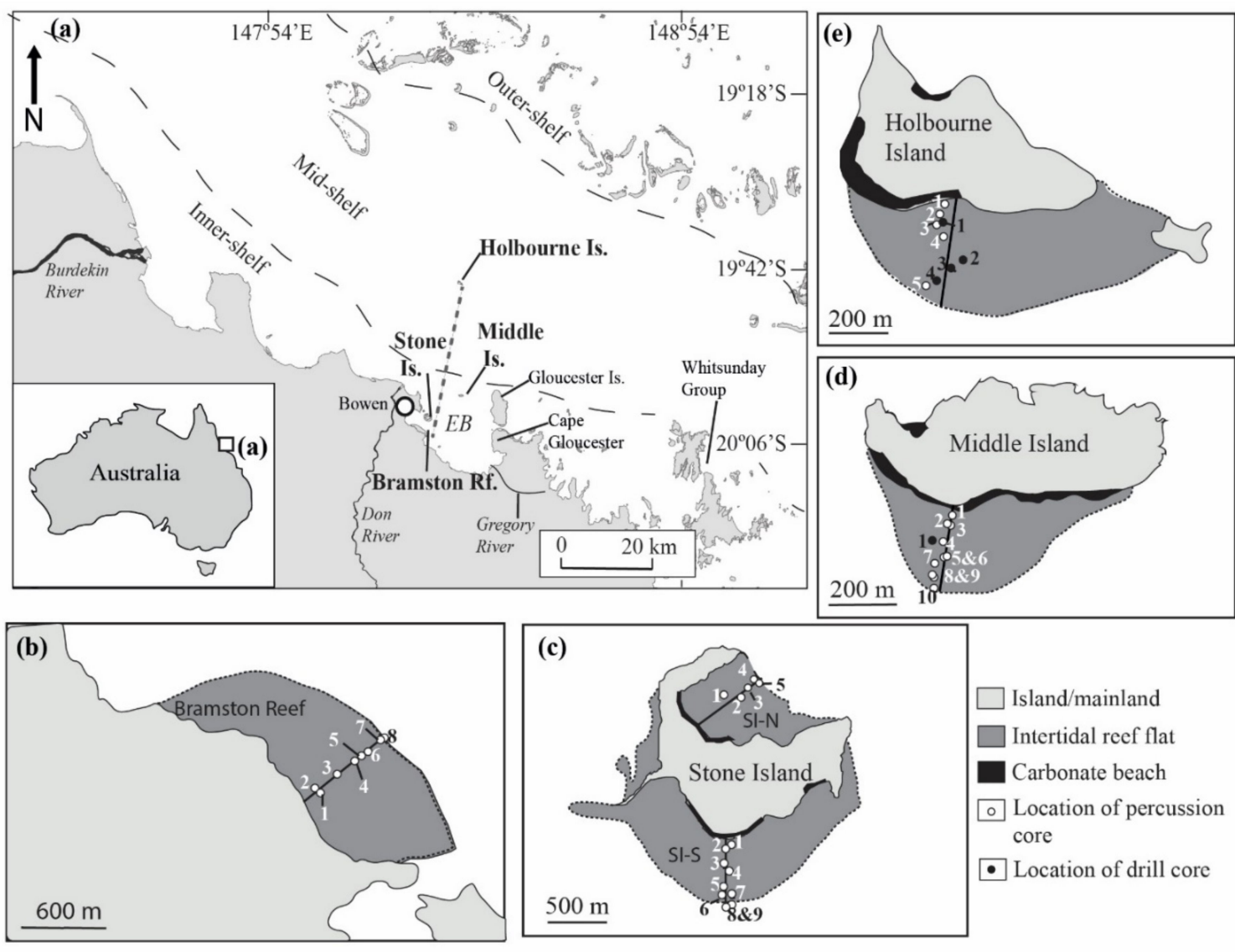

Figure 1. (a) Location of study sites and Edgecumbe Bay (EB) in Queensland, Australia. (b-e) Location of percussion core and drill core samples (numbered) at (b) Bramston Reef, (c) Stone Island North (SI-N) and South (SI-S), (d) Middle Island, and (e) Holbourne Island.

\section{Results}

\subsection{Nature and Depth of the Antecedent Surface}

The nature of and depth to the pre-Holocene antecedent surface varied across the shelf, generally shallowing inshore. Unconsolidated transgressive sands and lag gravels overlaying Pleistocene clay were recovered at a depth of 1.9-3.7 m below the present reef flat surface at the mainland-attached site (Bramston Reef). Compacted regolith clay was recovered $7.0 \mathrm{~m}$ below the present surface of the fringing reef flat at the inshore reef $10 \mathrm{~km}$ offshore (Middle Island), while a weathered last interglacial 
reef deposit and granite were each recovered (in separate cores) 5.9 and $8.1 \mathrm{~m}$ below the surface of the mid-shelf fringing reef flat (Holbourne Island), respectively (Table 1). The pre-Holocene surface was not identified at the inshore reef flats $3 \mathrm{~km}$ offshore (at Stone Island) because the cores did not penetrate to a sufficient depth (maximum $5.1 \mathrm{~m}$ penetration, at which depth Holocene reef material was recovered). Nevertheless, it is probable that the pre-Holocene surface beneath Stone Island's reefs would be comparable to the transgressive sands encountered elsewhere within Edgecumbe Bay at the mainland-attached reef $<3 \mathrm{~km}$ away (Bramston Reef) or the regolith clay recovered from the fringing inshore reef $\sim 8 \mathrm{~km}$ away (Middle Island). The water depth immediately seaward of the Stone Island reef slopes is $\sim 6-7 \mathrm{~m}$ [45], and thus the percussion cores at Stone Island that reached $5 \mathrm{~m}$ depth likely captured the majority of the reef structure.

Table 1. Summary of Holocene reef growth attributes at the study reefs. ${ }^{230} \mathrm{Th}$ ages are presented as years before present (1950 AD).

\begin{tabular}{|c|c|c|c|c|c|}
\hline Site & Bramston Reef & $\begin{array}{l}\text { Stone Island } \\
\text { South }\end{array}$ & $\begin{array}{l}\text { Stone Island } \\
\text { North }\end{array}$ & Middle Island & $\begin{array}{l}\text { Holbourne } \\
\text { Island }\end{array}$ \\
\hline $\begin{array}{l}\text { Distance offshore from } \\
\text { mainland coast near Bowen }\end{array}$ & $0 \mathrm{~km}$ & $3 \mathrm{~km}$ & $3 \mathrm{~km}$ & $10 \mathrm{~km}$ & $40 \mathrm{~km}$ \\
\hline Reef flat width (m) & 900 & 450 & 400 & 330 & 440 \\
\hline Number of cores collected & 8 & 9 & 5 & 11 & 9 \\
\hline Maximum core depth (m) & 4.6 & 5.1 & 5.0 & 7.2 & 8.3 \\
\hline Number of ${ }^{230} \mathrm{Th}$ ages in cores & 13 & 14 & 11 & 14 & 16 \\
\hline $\begin{array}{l}\text { Earliest recorded age of } \\
\text { initiation }(\mathrm{yBP})\end{array}$ & $5396 \pm 51$ & $7247 \pm 23$ & $7064 \pm 17$ & $7873 \pm 17$ & $7520 \pm 20$ \\
\hline Antecedent substrate & $\begin{array}{c}\text { Transgressive } \\
\text { sands and lag } \\
\text { gravels } \\
\text { overlying } \\
\text { Pleistocene clay }\end{array}$ & Not recovered & Not recovered & $\begin{array}{l}\text { Regolith clay or } \\
\text { unconsolidated } \\
\text { carbonate } \\
\text { sediments }\end{array}$ & $\begin{array}{l}\text { Last interglacial } \\
\text { reef or granite }\end{array}$ \\
\hline $\begin{array}{l}\text { Shallowest depth }{ }^{1} \text { to } \\
\text { antecedent surface (m) }\end{array}$ & 1.9 & $\mathrm{n} / \mathrm{a}$ & $\mathrm{n} / \mathrm{a}$ & 2.6 & 6.0 \\
\hline $\begin{array}{l}\text { Maximum depth }{ }^{1} \text { to antecedent } \\
\text { surface }(\mathrm{m})\end{array}$ & 3.7 & $>5.1$ & $>5.0$ & 7.0 & 8.1 \\
\hline $\begin{array}{c}\text { Time when } \sim 80 \% \text { of reef flat had } \\
\text { been developed }(y B P)^{2}\end{array}$ & 2000 & 5000 & 4000 & 6000 & 6000 \\
\hline $\begin{array}{l}\text { Range of average net vertical } \\
\text { accretion rates }(\mathrm{mm} / \mathrm{yr})^{3}\end{array}$ & $2.5-9.8$ & $0.3-4.8$ & $0.9-5.0$ & $3.5-7.6$ & $0.7-3.2$ \\
\hline $\begin{array}{l}\text { Number of coral genera } \\
\text { recorded in cores }\end{array}$ & 25 & 20 & 23 & 15 & At least 10 \\
\hline Reference & [39] & [45] & [45] & [44] & [46] \\
\hline
\end{tabular}

\subsection{Timing, Formation, and Style of Reef Growth}

Of all sites, the earliest age of Holocene reef initiation was determined for the inshore fringing reef $10 \mathrm{~km}$ from the mainland (Middle Island at $7873 \pm 17 \mathrm{yBP}$ ), which was closely followed by the mid-shelf fringing reef furthest offshore (Holbourne Island at $7520 \pm 20 \mathrm{yBP}$ ), then the inshore reef $3 \mathrm{~km}$ from the mainland (7247 $\pm 23 \mathrm{yBP}$ at SI-S; $7064 \pm 17 \mathrm{yBP}$ at SI-N), and subsequently two millennia later at the mainland-attached reef (Bramston Reef at $5396 \pm 51$ yBP). Notably, initiation at Bramston Reef occurred around 600 years after both the reef flats at Middle Island and Holbourne Island were almost entirely emplaced or developed (Figures 2 and 3). Thus, the entire period of Holocene reef development at mainland-attached Bramston Reef occurred after the majority of reef development at the other four sites. 


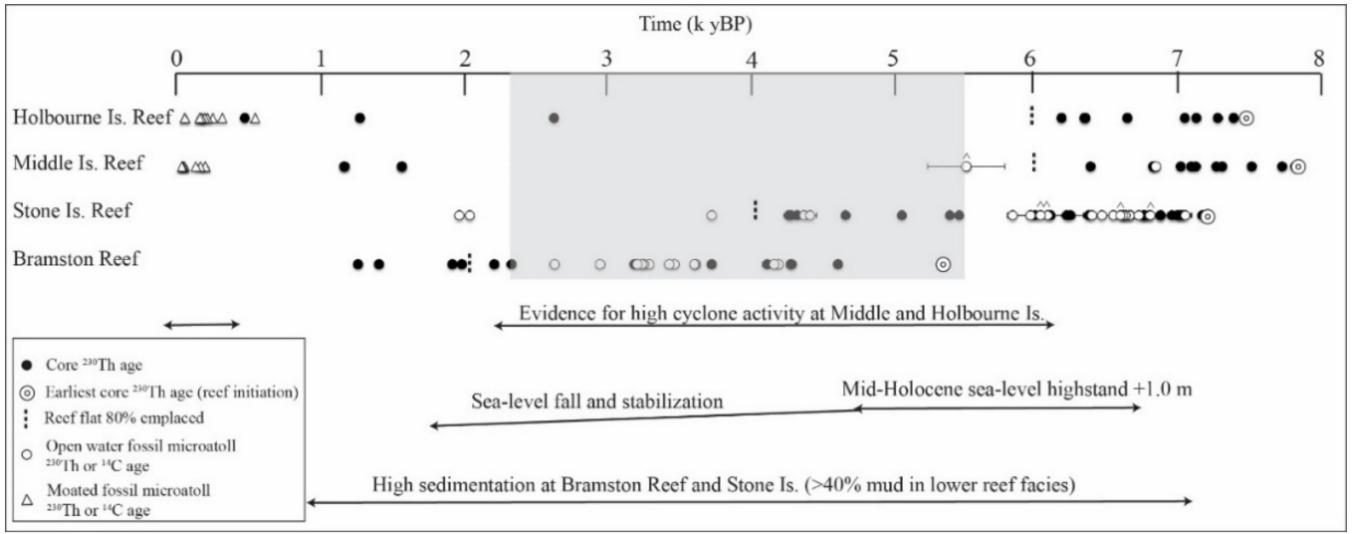

Figure 2. Timeline showing the main period of Holocene reef development for the four study areas. Uranium-thorium $\left(\mathrm{U}-\mathrm{Th} ;{ }^{230} \mathrm{Th}\right)$ and radiocarbon $\left({ }^{14} \mathrm{C}\right)$ ages are those obtained from within reef cores and fossil microatolls. Re-calibrated ${ }^{14} \mathrm{C}$ ages from other sources are also presented with two sigma age errors and are denoted by ^ (ages initially presented in [53,54] and re-calibrated using Calib 7.0 [55]). Note age errors are too small to warrant inclusion for the ${ }^{230}$ Th ages. The Perry and Smithers [28] 'reef-growth initiation hiatus' period is shaded grey.

(a)

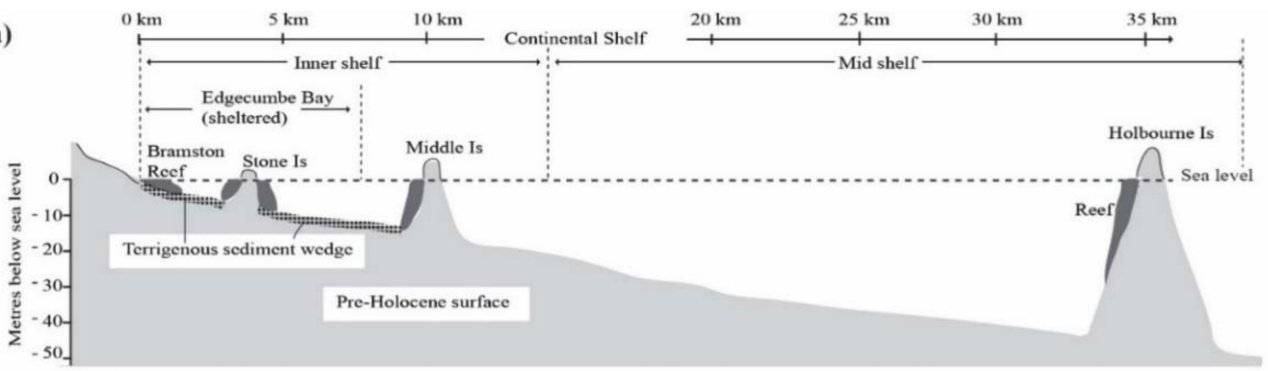

(b)
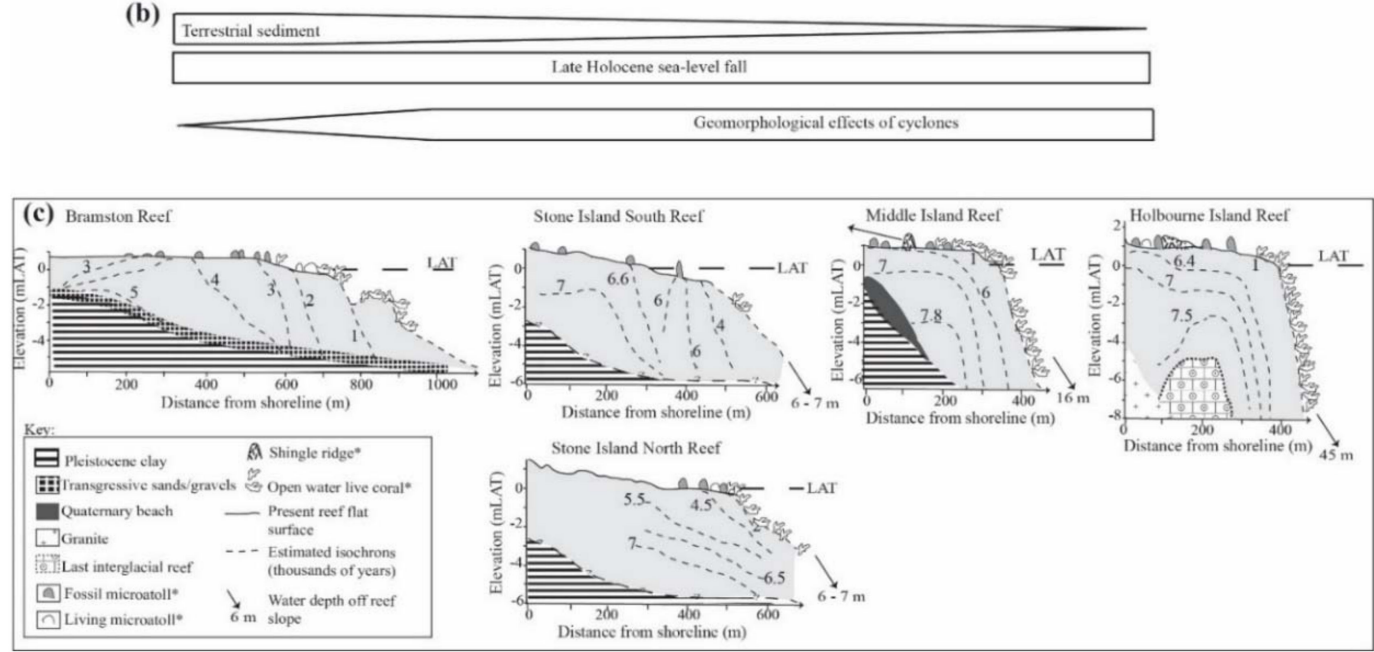

Figure 3. Schematic diagrams showing (a) the cross-section through the inner- and mid-shelf Great Barrier Reef extending seaward from the coast at Edgecumbe Bay; (b) the cross-shelf relative influence of environmental parameters; and (c) scaled conceptual reef growth models for each site based on the chronostratigraphies presented in $[39,44-46]$. Elevations are relative to lowest astronomical tide (LAT). In the key, ${ }^{*}$ denotes where features are not to scale.

The mode or style of reef development varied between sites along the transect, with growth modes represented by the isochrons in the reef chronostratigraphies (Figure 3). Isochrons were inferred based on the ${ }^{230} \mathrm{Th}$ ages in the reef cores and the microatoll ages across the reef flat surfaces. However, no major trends in growth mode (other than timing of reef development) were exhibited along the 
cross-shelf transect. The two fringing reefs further offshore at Holbourne and Middle Island developed under 'up and out' growth styles, similar to the classic Darwinian growth mode or model A in Kennedy and Woodroffe's [13] classification of fringing reef growth. These reefs accreted vertically to sea level in 'catch up' mode [56] during the early- to mid-Holocene ( 7800-6500 yBP), with subsequent reef flat progradation occurring within 1000-2000 years of initiation (Figure 3). A shallowing-upward trend, indicative of reef growth 'catching up' to sea level, was observed through the coarsening-upwards pattern of sediment facies in cores at all sites. Similar growth modes were displayed at two of the inshore sites (the mainland attached Bramston Reef and the embayed SI-N), whereby 'up and out' reef development occurred during the mid-Holocene (between 7000-4500 yBP at SI-N and 5500-4000 yBP at Bramston Reef). Once the mainland-attached reef had 'caught up' to sea level, seaward reef front progradation occurred from 3000 yBP onwards. However, this switch from 'up and out' to seaward progradation growth mode was not observed at SI-N. Conversely, the fringing reef $3 \mathrm{~km}$ offshore at SI-S developed by episodic landward and seaward reef progradation and infilling between $\sim 7000-5500$ yBP, comparable with Kennedy and Woodroffe's [13] model D. The inshore reefs at Bramston Reef and Stone Island continued to laterally prograde throughout the mid- to late-Holocene (until $4000 \mathrm{yBP}$ at Stone Island, while Bramston Reef is still laterally accreting, although not at sea level; Figure 3). Although no material aged $<4000$ yBP was recovered in cores from Stone Island, the inferred reef slope isochrons suggest that $\sim 150 \mathrm{~m}$ of reef slope lateral progradation occurred during the past 4000 years but did not reach sea level and form a reef flat (Figure 3). In contrast, a deceleration in net reef accretion was observed at sites further offshore (Middle and Holbourne Island), where negligible reef accretion has occurred over the past 6000 years. Despite reportedly high live coral cover at most sites (up to an average of $63 \%$ on reef flats) $[39,45,46]$, there has been little net accretion and reef growth over the past 6000 (at Middle and Holbourne Island) or 4000 years (at Stone Island). Taxonomic analyses of coral material within cores revealed differences in coral diversity between the sites, with recorded coral diversity being highest at the most inshore site (Bramston Reef; 25 coral genera identified) and decreasing offshore (15 and 10 coral genera identified at Middle and Holbourne Islands, respectively, Table 1).

The timing of reef flat development, estimated based on open-water (not moated) fossil microatolls on the reef flat or ages within the upper metre of cores, indicate that the earliest known time of reef flat development (Table 1) varied between sites according to reef initiation age and reef accretion rates. Reef flat development first occurred at Middle Island, $10 \mathrm{~km}$ offshore (by $6895 \pm 19$ yBP), where the earliest age of reef initiation was also recorded. The onset of reef flat development at further inshore sites (Bramston Reef and SI-N), however, occurred at least 2000 years later than at the other sites. Despite differences in the timing of reef flat development, at most sites the onset of reef flat development occurred rapidly within 1000-2000 years of reef initiation. Although reef flat development began much later at Bramston Reef $(4256 \pm 14 \mathrm{yBP})$, this mainland-attached site has developed the widest reef flat (900 $\mathrm{m}$ wide, Table 1). The reef flats further offshore are generally narrower (440 and $330 \mathrm{~m}$ wide, $40 \mathrm{~km}$ offshore at Holbourne Island, and $10 \mathrm{~km}$ offshore at Middle Island, respectively), but prograde into deeper water $(16-45 \mathrm{~m})$ than those inshore $(6-7 \mathrm{~m})$.

\subsection{Reef Accretion Rates and Sedimentology}

The material in the sediment cores were divided into reef facies according to variations in the size and composition of reef matrix sediments (see Table 2). At all sites, the sediment matrix typically coarsened upwards, with reef facies A and B comprising the upper 0.8-1.5 m of cores at Bramston Reef, SI-S, Middle Island, and Holbourne Island, and the upper $2.5 \mathrm{~m}$ of cores at SI-N. Reef facies C, D and $\mathrm{E}$ comprised the remainder of the cores. The reef matrix sediments were muddier and contained more terrigenous material closer to the mainland. The $<63 \mu \mathrm{m}$ mud fraction averaged $53.8 \pm 17.4 \%$ and $47.8 \pm 13.9 \%$ in muddy facies D at the furthest inshore sites (Bramston Reef and SI-S), respectively, compared to just $18.0 \pm 8.3 \%$ in the muddy facies $C$ at the mid-shelf site (Holbourne Island). The reef sediment matrix throughout the cores from the two further offshore sites (Middle and Holbourne Islands) was dominated by carbonate sediments, with terrigenous fractions ranging from $4.0 \pm 0.5$ 
to $32.1 \pm 10.2 \%$ at Middle Island and from $2.6 \pm 1.3$ to $7.2 \pm 3.9 \%$ at Holbourne Island (Table 2). In comparison, cores from the further inshore reefs contained higher terrigenous sediment fractions (up to $53.0 \pm 2.6$ and $29.5 \pm 9.5 \%$ at Bramston Reef and SI-S, respectively). Acid digestions revealed that terrigenous sediments were the dominant component of the $<63 \mu \mathrm{m}$ (mud) fraction within cores from inner Edgecumbe Bay.

Average vertical reef accretion rates across all sites varied between 0.3 and $9.8 \mathrm{~mm} / \mathrm{yr}$, which are considered to be relatively common for fringing reefs, where vertical accretion rates between 2 and $7 \mathrm{~mm} / \mathrm{yr}$ have been reported from the GBR [13]. Vertical accretion rates were highest (up to $9.8 \mathrm{~mm} / \mathrm{yr}$ ) at the mainland-attached site (Bramston Reef) and were comparatively low at both the island embayment site (SI-N, generally $0.9-1.7 \mathrm{~mm} / \mathrm{yr}$ ) and the mid-shelf reef (Holbourne Island, $0.7-3.2 \mathrm{~mm} / \mathrm{yr}$ ) (Table 1). In general, higher vertical accretion rates were associated with higher terrigenous and mud content of the reef matrix sediments (Figure 4). Accretion rates $>4 \mathrm{~mm} / \mathrm{yr}$ typically coincided with muddy sediment facies, where mud contents of the reef matrix sediments were $>40 \%$ (Figure 4 ), and largely comprised of terrigenous sediment.
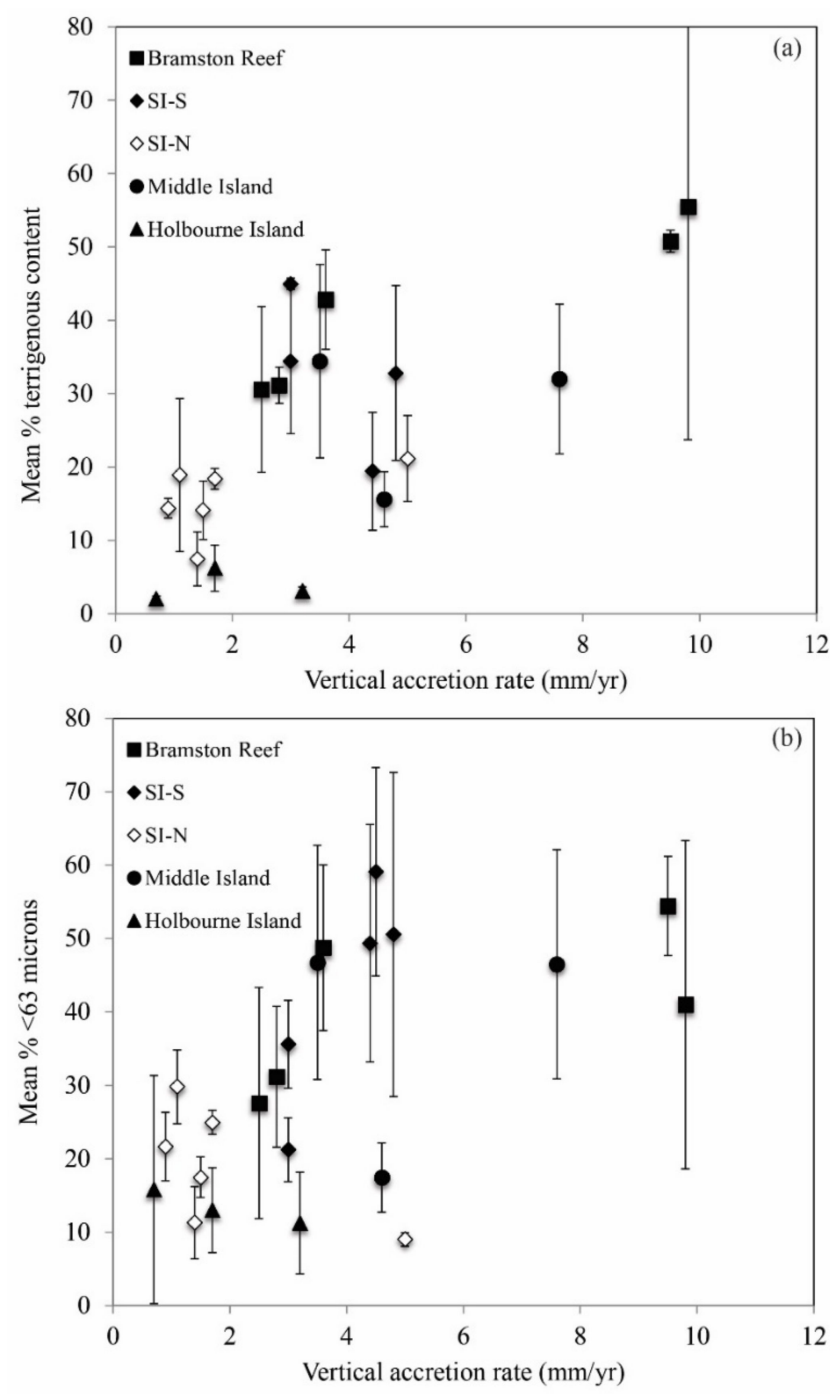

Figure 4. Estimated vertical reef accretion rates (based on ${ }^{230} \mathrm{Th}$ ages of coral material within reef cores) and (a) the mean terrigenous content or (b) the mean mud content $(<63 \mu \mathrm{m})$ of the sediment that contributed to the reef matrix during the time period for which each growth rate was estimated. Vertical error bars show one standard deviation for the terrigenous or mud content. SI-S is Stone Island South reef, and SI-N is Stone Island North reef. 
Table 2. A comparison of average $( \pm 1 \sigma)$ mud content ( $<63$ microns) and carbonate content $\left(\mathrm{CaCO}_{3}\right)$ of the sediment matrix within upper facies $(\mathrm{A}-\mathrm{B})$ and lower facies (C-E) in the percussion cores from each study site.

\begin{tabular}{|c|c|c|c|c|c|c|c|}
\hline Facies Name & Facies Description & & Bramston Reef & Stone Island South & Stone Island North & Middle Island & Holbourne Island \\
\hline \multirow[t]{2}{*}{ Facies A } & Intertidal sands & $\%$ mud & $14.2 \pm 5.2$ & $4.2 \pm 2.0$ & $9.6 \pm 5.2$ & $3.3 \pm 1.0$ & $2.1 \pm 0.8$ \\
\hline & & $\% \mathrm{CaCO}_{3}$ & $56.0 \pm 24.1$ & $96.9 \pm 2.3$ & $92.7 \pm 2.8$ & $96.0 \pm 0.5$ & $97.3 \pm 0.7$ \\
\hline \multirow[t]{2}{*}{ Facies B } & Reef framework, sandy matrix & $\%$ mud & $17.1 \pm 4.6$ & $8.6 \pm 4.4$ & $13.5 \pm 7.0$ & $9.8 \pm 4.4$ & $6.5 \pm 2.0$ \\
\hline & & $\% \mathrm{CaCO}_{3}$ & $73.1 \pm 12.0$ & $91.7 \pm 8.8$ & $87.4 \pm 6.0$ & $92.9 \pm 1.9$ & $97.4 \pm 1.3$ \\
\hline \multirow[t]{2}{*}{ Facies C } & Reef framework, muddy-sand matrix & $\%$ mud & $32.4 \pm 12.5$ & $35.9 \pm 12.7$ & $20.7 \pm 5.3$ & $22.0 \pm 10.2$ & $18.0 \pm 8.3$ \\
\hline & & $\% \mathrm{CaCO}_{3}$ & $63.6 \pm 13.7$ & $75.4 \pm 7.9$ & $81.7 \pm 9.7$ & $84.2 \pm 5.4$ & $92.8 \pm 3.9$ \\
\hline \multirow{2}{*}{ Facies D } & Reef framework, muddy matrix & $\%$ mud & $53.8 \pm 17.4$ & $47.8 \pm 13.9$ & $\mathrm{n} / \mathrm{a}$ & $46.5 \pm 15.6$ & $\mathrm{n} / \mathrm{a}$ \\
\hline & & $\% \mathrm{CaCO}_{3}$ & $55.6 \pm 7.1$ & $70.5 \pm 9.5$ & $\mathrm{n} / \mathrm{a}$ & $67.9 \pm 10.2$ & $\mathrm{n} / \mathrm{a}$ \\
\hline \multirow[t]{2}{*}{ Facies E } & Mud-silt unit & $\%$ mud & $41.1 \pm 19.1$ & $\mathrm{n} / \mathrm{a}$ & $\mathrm{n} / \mathrm{a}$ & $\mathrm{n} / \mathrm{a}$ & $\mathrm{n} / \mathrm{a}$ \\
\hline & & $\% \mathrm{CaCO}_{3}$ & $47.0 \pm 2.6$ & $\mathrm{n} / \mathrm{a}$ & $\mathrm{n} / \mathrm{a}$ & $\mathrm{n} / \mathrm{a}$ & $\mathrm{n} / \mathrm{a}$ \\
\hline
\end{tabular}




\section{Discussion}

\subsection{Reef Foundations}

The last interglacial reef foundations were only recovered at the mid-shelf fringing reef (Holbourne Island), with various terrestrial foundations underlying the Holocene reefs further inshore at Middle Island and Bramston Reef. The recovery of non-reefal antecedent surfaces in the reef cores is generally interpreted as indicating the absence of the last interglacial reef development at that location. However, the possibility that a fringing reef existed at the inshore sites (Middle Island, Stone Island and Bramston Reef) during the last interglacial period could be reasonably expected, despite no recovery of last interglacial reef material at these locations. This might particularly be the case at Middle Island $10 \mathrm{~km}$ offshore, given its proximity to Holbourne Island and Hayman Island (located $28 \mathrm{~km}$ north and $58 \mathrm{~km}$ south-east of Middle Island, and 35 and $20 \mathrm{~km}$ offshore, respectively), where both those fringing reefs developed upon last interglacial reef foundations [16]. Furthermore, the depth of Holocene reef initiation was comparable between Middle Island $(7.0 \mathrm{~m})$ and Holbourne Island $(8.1 \mathrm{~m})$ (Table 1) and Holocene reef development has flourished at all sites.

The last interglacial reef provides the foundation for all mid-shelf fringing and platform reefs in the GBR studied to date [16,57,58] including Holbourne Island [46]. However, the last interglacial reef foundations have not yet been recovered beneath reefs within $\sim 20 \mathrm{~km}$ of the mainland. The possibility that reef growth did occur in inshore locations but that it has not been preserved due to weathering/erosion [59] is rarely considered [20]. Examples of inshore reefs comprised of mixed terrigenous and carbonate material have been preserved in the Pleistocene record on the GBR [60], and in the longer geological record elsewhere, including in Spain [61], England [62], and Indonesia [63,64], revealing the potential of inshore reefs to have existed prior to the Holocene. In any case, detrital-dominated reefs that are comprised of both carbonate and terrigenous material, such as the Holocene inshore reefs at Bramston Reef, Stone Island, and Middle Island, might be more prone to physical disintegration [65] than those dominated by a cemented framework, typical of reefs further offshore [17] such as Holbourne Island ( $\sim 35 \mathrm{~km}$ offshore) and Hayman Island ( 20 km offshore). Of all the reef flats on the GBR, inshore reef flats would be exposed for the longest period of time during glacial episodes, due to their location on the shallower inner-shelf, further enhancing the potential for such fossil last interglacial reefs to be weathered and eroded (providing the reefs existed). The recovery of the last interglacial reef at Holbourne Island $35 \mathrm{~km}$ offshore [46] and Hayman Island $20 \mathrm{~km}$ offshore [16] represents two of the furthest inshore records of the last interglacial foundations for the central GBR. New chronostratigraphic investigations of inshore reefs on the GBR in the future will determine whether reefs flourished on the inner-shelf during the last interglacial and if such reefs remain preserved in the geological record.

\subsection{Controls on Reef Initiation across the Shelf}

Reef initiation at all sites except the mainland-attached Bramston Reef occurred between $7873 \pm 17$ and sometime prior to $7064 \pm 17$ yBP, at least $\sim 500-1000$ years after the post-glacial marine transgression (PGMT) flooded foundations. This is comparable to many fringing reefs of the GBR where the average reef initiation age is reported as $7100 \mathrm{yBP}$ [10]. Differences in the timing of reef initiation across the shelf could be a function of two factors: (1) the nature of the underlying foundations [66], with unconsolidated sands and gravels that underlie the mainland-attached reef presenting a more challenging substrate for coral colonisation compared with the solid antecedent surfaces recovered further offshore at Middle and Holbourne Islands; or (2) relative sea-level fall since $\sim 6000$ yBP [22] improving the availability of favourable photosynthetically available radiation (PAR) in inshore locations and thus enhancing coral reef development in shallow, turbid environments close to the mainland, such as Bramston Reef [67]. Perry and Smithers [28] identified a reef-building 'hiatus' on the inshore GBR, between $~ 5500$ and $2300 \mathrm{yBP}$, for which no known reef initiation occurred. The initiation age of $5396 \pm 51$ yBP from Bramston Reef is the first record of reef initiation in the inner 
GBR during this hiatus period. Although it could be argued that reef initiation might have preceded the onset of the hiatus period, but was not captured in our chronostratigraphic record, the major period of Holocene reef-building at Bramston Reef occurred within the hiatus window (Figure 2). A similar reef growth hiatus was observed by Dechnik et al. [68] on the mid-outer platform reefs of the southern and northern GBR, lasting from $\sim 3600$ to $1600 \mathrm{yBP}$. This hiatus was not observed in the central GBR region, however, with mid-outer platform reefs accreting throughout the mid-late Holocene. This is consistent with our findings from Bramston Reef, which accreted well into the reef growth hiatus period identified by Dechnik et al. [68] suggesting that the absence of a hiatus in central GBR platform reef growth is also applicable to inshore fringing reefs in this region.

\subsection{Role of Exposure Conditions and Terrigenous Sediments on Reef Development and Preservation}

The depth and shape of the underlying substrate provide important controls on accommodation space for coral reef development and resulting reef morphology [10]. The pre-reefal substrates in inner Edgecumbe Bay are shallow $(6-7 \mathrm{~m})$ and gently sloping, providing extended lateral accommodation space for wider reef flat development closer to the Queensland coast $(900 \mathrm{~m}$ at mainland-attached Bramston Reef). This contrasts with the steep foundations surrounding Holbourne ( $\sim 45 \mathrm{~m})$ and Middle Islands $(16 \mathrm{~m})$, further offshore, where steeper fore-reef slopes and narrower reef flats have formed due to limited progradation as the reefs accrete into deeper water on steeper slopes (440 and $330 \mathrm{~m}$ wide at Holbourne Island and Middle Island, respectively) (Figure 3). However, vertical accommodation space on the inner-shelf would be comparatively limited, owing to the shallow depths and the lower effective PAR depth (i.e., higher turbidity) for coral growth [20]. Moreover, it has been inferred that cyclones during the mid-Holocene influenced the development of the fringing reefs at Middle and Holbourne Islands through erosion of reef framework and production of coral rubble material $[44,46]$. The greater influence of cyclones at these sites may have also reduced the width of reef flats $(<440 \mathrm{~m}$ wide) through episodic erosion of the outer reef framework, which slowed net reef flat accretion.

Cross-shelf energy and export gradients are also reflected in the composition of the internal reef structure and matrix captured in reef cores. Fine-grained $(<63 \mu \mathrm{m})$ terrigenous sediments accumulated within the reef structure at further inshore sites (Stone Island reefs and Bramston Reef, Table 2), suggesting that these inshore reefs are characterised by low export [29]. The deposition of fine sediments may lessen the destructive effects of biological and physical reef erosion, enhancing the preservation of the reef framework, and potentially enhancing vertical accretion rates [69], as has been found elsewhere in the central inshore GBR at Paluma Shoals [70] and Middle Reef [29]. Indeed, the average vertical reef accretion rate estimated for mainland-attached Bramston Reef was the highest recorded along the cross-shelf transect $(\sim 10 \mathrm{~mm} / \mathrm{yr})$ and terrigenous mud-rich units that lack coral clasts were found throughout Bramston Reef cores [39]. Furthermore, inshore reefs contained the highest coral palaeo-community diversity (25 different genera identified at Bramston Reef compared with 15 at Middle Island; Table 1), while cores from further offshore reefs (Middle and Holbourne Islands) contained higher amounts of coralline-algal encrusted and bioeroded coral rubble (56-82\% branching rubble at Middle Island), consistent with descriptions of storm-deposited detrital material [71]. The higher taxonomic diversity of corals found in cores collected from inshore sites is likely a reflection of the superior preservation of the coral material at low-energy, sheltered inshore locations, rather than an actual representation of coral palaeo-diversity. The preservation state of in situ corals in cores further supports this assertion, whereby coral clasts were better preserved in cores from Bramston Reef and SI-S, where excellent preservation of corallites and fine skeletal structure allowed for much easier post-mortem identification of coral clasts compared with the cores from Middle and Holbourne Islands, which were dominated by bioeroded and encrusted storm rubble. We suggest that palaeo-ecological records from inshore reefs in relatively low-energy, protected settings (where sedimentation is relatively high) may provide more accurate information on past coral diversity than comparable records from reefs further offshore, which lack high amounts $(>40 \%)$ of muddy terrigenous sediment and are more prone to export/re-working of coral material. These 
findings support Pandolfi and Minchin's [72] assertion that coral death assemblages at low-energy sites (compared with high-energy sites) more accurately represented the taxonomic composition of living coral communities.

\subsection{Evidence for Changes in Disturbance Regimes since European Settlement}

The variations in Holocene reef development between fringing reefs across the GBR shelf that are exposed to different degrees of anthropogenic and natural stressors can provide important insights to further understand present reef condition. An understanding of how coral reefs in Edgecumbe Bay developed and were influenced by various stressors over the Holocene is required to evaluate the significance of reported declines in coral cover since European settlement [73], and to contextualise the present reef condition where human impacts are implicated. Notably, all reefs in Edgecumbe Bay were substantially emplaced well before European settlement of Bowen and surrounding catchments $\sim 1860 \mathrm{AD}$, and were in a lower accretion stage long before more recent records of the reef condition, as captured in historical photographs or contemporary datasets, were collected [45]. Our millennial-scale records derived from reef cores demonstrate that reefs in Edgecumbe Bay have always been exposed to (and have recovered from) episodic cyclones and sedimentation, based on the high proportion of storm-derived coral rubble in cores from Middle Island, and the mud-rich facies in cores at Bramston Reef that represent periods of high terrigenous sediment input that occurred well before European settlement.

Determining the effects of terrigenous input on the present condition of reefs in Edgecumbe Bay and those further offshore on the mid- and outer-shelf is complex. The main potential anthropogenic impacts on inshore coral reefs of the GBR are related to the increase in the runoff of land-based sediment and nutrients that have followed European land use changes in coastal catchments [32]. Accordingly, a catchment-to-reef understanding of the sources, transport, and fate of these sediments and nutrients is required to fully understand their impacts. The spatial impact of increased sediment delivery since European settlement on coral reefs of the GBR is dependent on a number of factors, including how much the erosion and export of sediments and nutrients from the key coastal catchments have increased [74], the degree to which any reef is exposed to river flood plumes (which is related to the distance of the reef from the river mouth and the size of the river discharge), the natural environmental conditions under which the coral reef has developed (i.e., turbidity tolerant species), the character of sediments exported from the catchment (particle size, mineralogy and organic content) and the geomorphology and bathymetry of the coastline and adjacent continental shelf, which influence sediment storage and flushing periods (e.g., see Bainbridge et al. [75]). A combination of geographic good fortune and inshore hydrodynamic context means that the fringing reefs of Edgecumbe Bay are relatively remote and generally isolated from flood plume exposure from the larger catchments that export greatest sediment loads that have significantly increased since European settlement (e.g., the Burdekin River [32]). As a result, the potential impacts of increased sediment delivery on the reefs that we examined will be principally related to changes in the Don River catchment or will be associated with localised runoff from the island catchments. While our data show that terrigenous sediment forms a minor part of the internal fringing reef structure at Holbourne and Middle Islands, we are unable to decipher whether this sediment is derived from the island or from regional river discharge (i.e., Burdekin or Don Rivers) without sediment tracing analysis. This analysis is presently underway [75]; however, even if a coastal catchment source is confirmed, it is difficult to quantify changes in sediment exposure at the sites further offshore, as the majority of sediments exported are deposited and retained within a few kilometres from the river mouth [76] and the residual loads carried further are comparatively smaller and differences over time difficult to measure and detect. The nearshore and mainland-attached fringing reefs of Stone Island and Bramston Reef clearly developed in naturally turbid settings, and so the level of increase in sediment exposure would need to be considerable to impact these sites. In fact, there is little evidence that the health of Bramston Reef has changed over the past 150 years [39], although the fringing reef in the south 
of Stone Island (SI-S) appears to have declined since European settlement, potentially as a result of localised sediment erosion from the island catchment [45]. Future research in this space would benefit from combining geomorphological Holocene records of reef development and sediment input with more recent records of coral growth (linear extension and calcification) [77] and geochemical analyses of Porites coral skeletons as proxy records for sediment and nutrient input (e.g., [33,78,79]) that extend from pre-European settlement to the present. Such records would be extremely valuable in understanding anthropogenic effects on nearshore fringing reefs. This study highlights the challenges and complexity of factors that must be considered when understanding changes in fringing reef condition over the Holocene and their potential causes, and when attempting to project their future trajectories into the Anthropocene.

\section{Conclusions}

A comparison of fringing reef development along a cross-shelf transect on the central Great Barrier Reef revealed that the reefs initiated between $7873 \pm 17$ and $5396 \pm 51$ yBP; initiation occurred at a greater depth further offshore, and reef initiation was delayed at the most inshore site. The most inshore reef flat was the widest $(900 \mathrm{~m})$ and the lowest in elevation $(\sim 0.6 \mathrm{~m}$ LAT). The muddier inshore reefs boasted the highest reef accretion rates during the Holocene (up to $10 \mathrm{~mm} / \mathrm{yr}$ ), and also comprised the highest taxonomic coral community diversity, which we attribute to relatively high sedimentation and hence superior preservation. Despite these variations, all reefs accreted rapidly, and reef flats were emplaced within a 1000 or 2000-year period following initiation, after which negligible reef flat progradation occurred at any site. Variations in the timing of reef initiation between sites resulted from either a) differences in the composition of the antecedent surface that varied across-shore, with unconsolidated substrates at the mainland-attached Bramston Reef being most difficult for coral colonisation, or b) late-Holocene relative sea-level fall allowing for enhanced PAR and reef growth at the furthest inshore site. The sea level and the shape of the underlying substrate influenced the accommodation space at each site, and influenced the timing and nature of vertical reef accretion and reef flat progradation. Furthermore, the greater exposure to the physically destructive effects of cyclones of reefs further offshore in deeper water (Middle and Holbourne Islands) was evident in the reef chronostratigraphies, while the impacts of terrestrial sedimentation were greater further inshore (at Bramston Reef and Stone Island). Although cyclones clearly affect reefs closer inshore, the geomorphology of inshore reefs is affected by a range of controlling factors, including terrestrial sedimentation, the impacts of which are reduced at reefs on the mid- and outer-shelf. Future work in this field should be directed to developing new cross-shelf explorations of Holocene coral reef development on the GBR, in order to help determine whether the patterns observed in this study are representative of the wider GBR region. Furthermore, extending the cross-shelf transect to the outer-shelf reefs of the GBR would enhance our understanding of Holocene sea-level controls (especially hydro-isostatic effects) on reef development, particularly through the use of open-water (not moated) fossil microatolls as proxy sea-level indicators.

Supplementary Materials: The following are available online at http:/ /www.mdpi.com/1424-2818/10/4/110/s1, Table S1: List of all previously published percussion and drill cores, core length, penetration depth from reef flat surface, compaction rate, co-ordinates. Table S2: Multicollector inductively coupled plasma mass spectrometer uranium-thorium (U-Th) data of core samples from Bramston Reef, Stone Island, Middle Island and Holbourne Island, central Great Barrier Reef.

Author Contributions: Conceptualization, E.J.R., S.G.S., and S.E.L.; Data curation, E.J.R.; Funding acquisition, E.J.R., S.G.S., S.E.L., and J.-x.Z.; Investigation, E.J.R., S.G.S., S.E.L., T.R.C., and J.-x.Z.; Methodology, E.J.R., S.G.S., T.R.C., and J.-x.Z.; Project administration, E.J.R., S.G.S., and T.RC.; Resources, T.R.C. and J.-x.Z.; Supervision, S.G.S. and S.E.L.; Visualization, E.J.R.; Writing—original draft, E.J.R.; Writing—review \& editing, E.J.R., S.G.S., S.E.L, T.R.C., and J.-x.Z.

Funding: This research contributed to the author E.R.'s doctoral thesis at James Cook University. The research was funded by the National Environmental Research Program, grant number 1.3, along with additional support from the Great Barrier Reef Marine Park Authority (Science for Management Award to E.R.), and an Australian Institute of Nuclear Science and Engineering grant (14/003). 
Acknowledgments: The authors would like to acknowledge Q. Hua (Australian Institute of Nuclear Science and Technology) for radiocarbon dating, and the staff of the Radiogenic Isotope Facility at the University of Queensland for U-Th dating. Our acknowledgements are extended to all volunteer field and laboratory assistance received. All data were collected under Great Barrier Reef Marine Park Authority permit number G12/34979.1.

Conflicts of Interest: The authors declare no conflict of interest. The funders had no role in the design of the study; in the collection, analyses, or interpretation of data; in the writing of the manuscript, and in the decision to publish the results.

\section{References}

1. Done, T.J. Effects of tropical cyclone waves on ecological and geomorphological structures on the Great Barrier Reef. Cont. Shelf. Res. 1992, 12, 859-872. [CrossRef]

2. Risk, M.J. Assessing the effects of sediments and nutrients on coral reefs. Curr. Opin. Environ. Sustain. 2014, 7, 108-117. [CrossRef]

3. Hoegh-Guldberg, O.; Mumby, P.J.; Hooten, A.J.; Steneck, R.S.; Greenfield, P.; Gomez, E.; Harvell, C.D.; Sale, P.F.; Edwards, A.J.; Caldeira, K.; et al. Coral reefs under rapid climate change and ocean acidification. Science 2007, 318, 1737-1742. [CrossRef] [PubMed]

4. Jackson, J.B.C.; Kirby, M.X.; Berger, W.H.; Bjorndal, K.A.; Botsford, L.W.; Bourque, B.J.; Bradbury, R.H.; Cooke, R.; Erlandson, J.; Estes, J.A.; et al. Historical overfishing and the recent collapse of coastal ecosystems. Science 2001, 293, 629. [CrossRef] [PubMed]

5. Pastorok, R.; Bilyard, G. Effects of sewage pollution on coral-reef communities. Mar. Ecol. Prog. Ser. 1985, 21, 175-189. [CrossRef]

6. De'ath, G.; Fabricius, K.E.; Sweatman, H.; Puotinen, M. The 27-year decline of coral cover on the Great Barrier Reef and its causes. Proc. Natl. Acad. Sci. USA 2012, 109, 1-5. [CrossRef] [PubMed]

7. DeVantier, L.M.; De'ath, G.; Turak, E.; Done, T.J.; Fabricius, K.E. Species richness and community structure of reef-building corals on the nearshore Great Barrier Reef. Coral Reefs 2006, 25, 329-340. [CrossRef]

8. Hughes, T.P.; Kerry, J.T.; Baird, A.H.; Connolly, S.R.; Dietzel, A.; Eakin, C.M.; Heron, S.F.; Hoey, A.S.; Hoogenboom, M.O.; Liu, G.; et al. Global warming transforms coral reef assemblages. Nature 2018. [CrossRef] [PubMed]

9. Pandolfi, J.M.; Jackson, J.B.C. Ecological persistence interrupted in Caribbean coral reefs. Ecol. Lett. 2006, 9, 818-826. [CrossRef] [PubMed]

10. Smithers, S.G.; Hopley, D.; Parnell, K.E. Fringing and nearshore coral reefs of the Great Barrier Reef: Episodic Holocene development and future prospects. J. Coast. Res. 2006, 221, 175-187. [CrossRef]

11. Bruno, J.F.; Precht, W.F.; Vroom, P.S.; Aronson, R.B. Coral reef baselines: How much macroalgae is natural? Mar. Pollut. Bull. 2014, 80, 24-29. [CrossRef] [PubMed]

12. Hongo, C.; Lin, K.; Shen, C.C. Late Holocene reef ecosystem baseline: Field evidence from the raised reef terraces of Kodakara and Kikai Islands, Ryukyu Islands, Japan. Quat. Int. 2017, 455, 8-17. [CrossRef]

13. Kennedy, D.M.; Woodroffe, C.D. Fringing reef growth and morphology: A review. Earth-Sci. Rev. 2002, 57, 255-277. [CrossRef]

14. Montaggioni, L.F. History of Indo-Pacific coral reef systems since the last glaciation: Development patterns and controlling factors. Earth-Sci. Rev. 2005, 71, 1-75. [CrossRef]

15. Davies, P.J. Subsurface solution unconformities at Heron Island, Great Barrier Reef. In Proceedings of the 2nd International Coral Reef Symposium, Brisbane, Australia, 22 June-2 July 1974; pp. 573-578.

16. Hopley, D.; Mclean, R.F.; Marshall, J.; Smith, A.S. Holocene-Pleistocene boundary in a fringing reef: Hayman Island, North Queensland. Search 1978, 9, 323-325.

17. Davies, P.J.; Marshall, J.F.; Hopley, D. Relationships between reef growth and sea level in the Great Barrier Reef. In Proceedings of the 5th International Coral Reef Congress, Tahiti, French Polynesia, 27 May-1 June 1985; pp. 95-103.

18. Marshall, J.F. Cross-shelf and facies related variations in submarine cementation in the central Great Barrier Reef. In Proceedings of the 5th International Coral Reef Congress, Tahiti, French Polynesia, 27 May-1 June 1985; pp. 221-226.

19. Johnson, D.; Cuff, C.; Rhodes, E. Holocene reef sequences and geochemistry, Britomart reef, central Great Barrier Reef, Australia. Sedimentology 1984, 31, 515-529. [CrossRef] 
20. Partain, B.R.; Hopley, D. Morphology and development of the Cape Tribulation fringing reefs, Great Barrier Reef, Australia; Great Barrier Reef Marine Park Authority Technical Memorandum: Townsville, Australia, 1989.

21. Johnson, D.P.; Risk, M.J. Fringing reef growth on a terrigenous mud formation, Fantome Island, central Great Barrier Reef, Australia. Sedimentology 1987, 34, 275-287. [CrossRef]

22. Lewis, S.E.; Sloss, C.R.; Murray-Wallace, C.V.; Woodroffe, C.D.; Smithers, S.G. Post-glacial sea-level changes around the Australian margin: A review. Quat. Sci. Rev. 2013, 74, 115-138. [CrossRef]

23. Larcombe, P.; Carter, R.M.; Dye, J.; Gagan, M.K.; Johnson, D.P. New evidence for episodic post-glacial sea-level rise, central Great Barrier Reef, Australia. Mar. Geol. 1995, 127, 1-44. [CrossRef]

24. Chappell, J. Evidence for smoothly falling sea level relative to north Queensland, Australia, during the past 6,000 yr. Nature 1983, 302, 406-408. [CrossRef]

25. Lewis, S.E.; Wüst, R.A.J.; Webster, J.M.; Collins, J.; Wright, S.A.; Jacobsen, G. Rapid relative sea-level fall along north-eastern Australia between 1200 and 800cal.yrBP: An appraisal of the oyster evidence. Mar. Geol. 2015, 370, 20-30. [CrossRef]

26. Lewis, S.E.; Wüst, R.A.; Webster, J.M.; Shields, G.A. Mid-late Holocene sea-level variability in eastern Australia. Terra Nova 2008, 20,74-81. [CrossRef]

27. Leonard, N.D.; Zhao, J.X.; Welsh, K.J.; Feng, Y.X.; Smithers, S.G.; Pandolfi, J.M.; Clark, T.R. Holocene sea level instability in the southern Great Barrier Reef, Australia: High-precision U-Th dating of fossil microatolls. Coral Reefs 2016, 35, 625-639. [CrossRef]

28. Perry, C.T.; Smithers, S.G. Cycles of coral reef "turn-on", rapid growth and "turn-off" over the past 8500 years: A context for understanding modern ecological states and trajectories. Glob. Chang. Biol. 2011, 17, 76-86. [CrossRef]

29. Perry, C.T.; Smithers, S.G.; Gulliver, P.; Browne, N.K. Evidence of very rapid reef accretion and reef growth under high turbidity and terrigenous sedimentation. Geology 2012, 40, 719-722. [CrossRef]

30. Roff, G.; Clark, T.R.; Reymond, C.E.; Zhao, J.; Feng, Y.; McCook, L.J.; Done, T.J.; Pandolfi, J.M. Palaeoecological evidence of a historical collapse of corals at Pelorus Island, inshore Great Barrier Reef, following European settlement. Proc. R. Soc. B Biol. Sci. 2012, 280, 20122100. [CrossRef] [PubMed]

31. Browne, N.K.; Smithers, S.G.; Perry, C.T. Coral reefs of the turbid inner-shelf of the Great Barrier Reef, Australia: An environmental and geomorphic perspective on their occurrence, composition and growth. Earth-Sci. Rev. 2012, 115, 1-20. [CrossRef]

32. Kroon, F.J.; Kuhnert, P.M.; Henderson, B.L.; Wilkinson, S.N.; Kinsey-Henderson, A.; Abbott, B.; Brodie, J.E.; Turner, R.D.R. River loads of suspended solids, nitrogen, phosphorus and herbicides delivered to the Great Barrier Reef lagoon. Mar. Pollut. Bull. 2012, 65, 167-181. [CrossRef] [PubMed]

33. McCulloch, M.; Fallon, S.; Wyndham, T.; Hendy, E.; Lough, J.M.; Barnes, D. Coral record of increased sediment flux to the inner Great Barrier Reef since European settlement. Nature 2003, 421, 727-730. [CrossRef] [PubMed]

34. Waters, D.; Carroll, C.; Ellis, R.; Hateley, L.; McCloskey, G.L.; Packett, R.; Dougall, C. Fentie Modelling Reductions of Pollutant Loads Due to Improved Management Practices in the Great Barrier Reef Catchments-Whole of GBR; Technical Report; Queensland Government: Brisbane, Australia, 2014.

35. Fabricius, K.; De'ath, G.; McCook, L.; Turak, E.; Williams, D.M. Changes in algal, coral and fish assemblages along water quality gradients on the inshore Great Barrier Reef. Mar. Pollut. Bull. 2005, 51, 384-398. [CrossRef] [PubMed]

36. Larcombe, P.; Woolfe, K.J. Terrigenous sediments as influence upon Holocene nearshore coral reefs, central Great Barrier Reef, Australia. Aust. J. Earth Sci. 1999, 46, 141-154. [CrossRef]

37. Browne, N.K.; Smithers, S.G.; Perry, C.T. Geomorphology and community structure of Middle Reef, central Great Barrier Reef, Australia: An inner-shelf turbid zone reef subject to episodic mortality events. Coral Reefs 2010, 29, 683-689. [CrossRef]

38. Morgan, K.M.; Perry, C.T.; Johnson, J.A.; Smithers, S.G. Nearshore turbid-zone corals exhibit high bleaching tolerance on the Great Barrier Reef following the 2016 ocean warming event. Front. Mar. Sci. 2017, 4, 224. [CrossRef]

39. Ryan, E.J.; Smithers, S.G.; Lewis, S.E.; Clark, T.R.; Zhao, J.X. Chronostratigraphy of Bramston Reef reveals a long-term record of fringing reef growth under muddy conditions in the central Great Barrier Reef. Palaeogeogr. Palaeoclimatol. Palaeoecol. 2016, 441, 734-747. [CrossRef] 
40. Palmer, S.E.; Perry, C.T.; Smithers, S.G.; Gulliver, P. Internal structure and accretionary history of a nearshore, turbid-zone coral reef: Paluma Shoals, central Great Barrier Reef, Australia. Mar. Geol. 2010, 276, 14-29. [CrossRef]

41. Roff, G.; Zhao, J.X.; Pandolfi, J.M. Rapid accretion of inshore reef slopes from the central Great Barrier Reef during the late Holocene. Geology 2015, 43, 343-346. [CrossRef]

42. Kleypas, J.A.; Hopley, D. Reef development across a broad continental shelf, Southern Great Barrier Reef, Australia. In Proceedings of the 7th International Coral Reef Symposium, Guam, Micronesia, 22-27 June 1992; pp. 1129-1141.

43. Ryan, E.J. Fringing Reef Growth on the Central Great Barrier Reef: Signatures of Sea-Level Change, Storms and Sedimentation. Unpublished Ph.D. Thesis, James Cook University, Townsville, Australia, 2016.

44. Ryan, E.J.; Smithers, S.G.; Lewis, S.E.; Clark, T.R.; Zhao, J.X. The influence of sea level and cyclones on Holocene reef flat development: Middle Island, central Great Barrier Reef. Coral Reefs 2016, 35, 805-818. [CrossRef]

45. Ryan, E.J.; Lewis, S.E.; Smithers, S.G.; Clark, T.R.; Zhao, J.X. Multi-scale records of reef development and condition provide context for contemporary changes on inshore reefs. Glob. Planet. Chang. 2016, 146, 162-178. [CrossRef]

46. Ryan, E.J.; Smithers, S.G.; Lewis, S.E.; Clark, T.R.; Zhao, J.X.; Hua, Q. Fringing reef growth over a shallow last interglacial reef foundation at a mid-shelf high island: Holbourne Island, central Great Barrier Reef. Mar. Geol. 2018, 398, 137-150. [CrossRef]

47. Larcombe, P.; Costen, A.; Woolfe, K.J. The hydrodynamic and sedimentary setting of nearshore coral reefs, Central Great Barrier Reef shelf, Australia: Paluma Shoals, a case study. Sedimentology 2001, 48, 811-835. [CrossRef]

48. Lambeck, K.; Nakada, M. Late Pleistocene and Holocene sea-level change along the Australian coast. Palaeogeogr. Palaeoclimatol. Palaeoecol. 1990, 89, 143-176. [CrossRef]

49. Scoffin, T.P.; Stoddart, D.R. The nature and significance of microatolls. Philos. Trans. R. Soc. Lond. B 1978, 284, 99-122. [CrossRef]

50. Clark, T.R.; Roff, G.; Zhao, J.X.; Feng, Y.X.; Done, T.J.; Pandolfi, J.M. Testing the precision and accuracy of the U-Th chronometer for dating coral mortality events in the last 100 years. Quat. Geochronol. 2014, 23, 35-45. [CrossRef]

51. Clark, T.R.; Zhao, J.X.; Roff, G.; Feng, Y.X.; Done, T.J.; Nothdurft, L.D.; Pandolfi, J.M. Discerning the timing and cause of historical mortality events in modern Porites from the Great Barrier Reef. Geochim. Cosmochim. Acta 2014, 138, 57-80. [CrossRef]

52. Zhou, H.; Zhao, J.; Qing, W.; Feng, Y.; Tang, J. Speleothem-derived Asian Summer Monsoon variations in Central China, 54-46ka. J. Quat. Sci. 2011, 26, 781-790. [CrossRef]

53. Chappell, J.; Chivas, A.; Wallensky, E.; Polach, H.A.; Aharon, P. Holocene palaeo-environmental changes, central to north Great Barrier Reef inner zone. J. Aust. Geol. Geophys. 1983, 8, 223-235.

54. Hopley, D. Contrasting evidence for Holocene sea levels with special reference to the Bowen-Whitsunday area of Queensland. In Geographical Essays in Honour of Gilbert J. Butland; Douglas, I., Hobbs, J.E., Pigram, J.J., Eds.; University of New England: Armidale, Australia, 1975; pp. 51-84.

55. Stuiver, M.; Reimer, P.J. Extended $14 \mathrm{C}$ data base and revised Calib $3.014 \mathrm{C}$ age calibration program. Radiocarbon 1993, 35, 215-230. [CrossRef]

56. Neumann, A.C.; Macintyre, I.G. Reef response to sea level rise: Keep-up, catch-up or give-up. In Proceedings of the 5th Int Coral Reef Congress, Tahiti, French Polynesia, 27 May-1 June 1985; pp. 105-110.

57. Kleypas, J.A. Coral reef development under naturally turbid conditions: Fringing reefs near Broad Sound, Australia. Coral Reefs 1996, 15, 153-167. [CrossRef]

58. Dechnik, B.; Webster, J.M.; Webb, G.E.; Nothdurft, L.; Dutton, A.; Braga, J.C.; Zhao, J.X.; Duce, S.; Sadler, J. The evolution of the Great Barrier Reef during the Last Interglacial Period. Glob. Planet. Chang. 2017, 149, 53-71. [CrossRef]

59. Purdy, E.G. Reef Configuration: Cause and Effect. Soc. Econ. Paleontol. Mineral. 1974, 18, 9-76.

60. Webster, J.M.; Davies, P.J. Coral variation in two deep drill cores: Significance for the Pleistocene development of the Great Barrier Reef. Sediment. Geol. 2003, 159, 61-80. [CrossRef]

61. Martin, J.M.; Braga, J.C.; Rivas, P. Coral successions in Upper Tortonian reefs in SE Spain. Lethaia 1989, 22, 271-286. [CrossRef] 
62. Insalaco, E. Facies and palaeoecology of Upper Jurassic (Middle Oxfordian) coral reefs in England. Facies 1999, 40, 81-100. [CrossRef]

63. Santodomingo, N.; Novak, V.; Pretkovic, V.; Marshall, N.; Di Martino, E.; Giudice Cappelli, E.L.; Rösler, A.; Reich, S.; Braga, J.C.; Renema, W.; et al. A diverse patch reef from turbid waters in the middle Miocene (East Kalimantan, Indonesia). Palaios 2015, 30, 128-149. [CrossRef]

64. Wilson, M.E.J.; Lokier, S.W. Siliciclastic and volcaniclastic influences on equatorial carbonates: Insights from the Neogene of Indonesia. Sedimentology 2002, 49, 583-601. [CrossRef]

65. Smithers, S.; Larcombe, P. Late Holocene initiation and growth of a nearshore turbid-zone coral reef: Paluma Shoals, central Great Barrier Reef, Australia. Coral Reefs 2003, 22, 499-505. [CrossRef]

66. Cabioch, G.; Montaggioni, L.F.; Faure, G. Holocene initiation and development of New Caledonian fringing reefs, SW Pacific. Coral Reefs 1995, 14, 131-140. [CrossRef]

67. Anthony, K.R.N.; Fabricius, K.E. Shifting roles of heterotrophy and autotrophy in coral energetics under varying turbidity. J. Exp. Mar. Biol. Ecol. 2000, 252, 221-253. [CrossRef]

68. Dechnik, B.; Webster, J.M.; Webb, G.E.; Nothdurft, L.; Zhao, J.X. Successive phases of Holocene reef flat development: Evidence from the mid- to outer Great Barrier Reef. Palaeogeogr. Palaeoclimatol. Palaeoecol. 2017, 466, 221-230. [CrossRef]

69. Tudhope, A.W.; Scoffin, T.P. Growth and structure of fringing reefs in a muddy environment, South Thailand. J. Sediment. Res. Sect. A Sediment. Petrol. Process. 1994, 64, 752-764. [CrossRef]

70. Perry, C.T.; Smithers, S.G.; Gulliver, P. Rapid vertical accretion on a "young" shore-detached turbid zone reef: Offshore Paluma Shoals, central Great Barrier Reef, Australia. Coral Reefs 2013, 32, 1143-1148. [CrossRef]

71. Blanchon, P.; Jones, B.; Kalbfleisch, W. Anatomy of a fringing reef around Grand Cayman: Storm rubble, not coral framework. J. Sediment. Res. 1997, 67, 1-16.

72. Pandolfi, J.M.; Minchin, P. A comparison of taxonomic composition and diversity between reef coral life and death assemblages in Madang Lagoon, Papua New Guinea. Palaeogeogr. Palaeoclimatol. Palaeoecol. 1995, 119, 321-341. [CrossRef]

73. Clark, T.R.; Leonard, N.D.; Zhao, J.-X.; Brodie, J.; McCook, L.J.; Wachenfeld, D.R.; Duc Nguyen, A.; Markham, H.L.; Pandolfi, J.M. Historical photographs revisited: A case study for dating and characterizing recent loss of coral cover on the inshore Great Barrier Reef. Sci. Rep. 2016, 6, 19285. [CrossRef] [PubMed]

74. Bartley, R.; Croke, J.; Bainbridge, Z.T.; Austin, J.M.; Kuhnert, P.M. Combining contemporary and long-term erosion rates to target erosion hot-spots in the Great Barrier Reef, Australia. Anthropocene 2015, 10, 1-12. [CrossRef]

75. Bainbridge, Z.; Lewis, S.; Bartley, R.; Fabricius, K.; Collier, C.; Waterhouse, J.; Garzon-Garcia, A.; Robson, B.; Burton, J.; Wenger, A.; et al. Fine sediment and particulate organic matter: A review and case study on ridge-to-reef transport, transformations, fates, and impacts on marine ecosystems. Mar. Pollut. Bull. 2018, 135, 1205-1220. [CrossRef]

76. Lewis, S.E.; Olley, J.; Furuichi, T.; Sharma, A.; Burton, J. Complex sediment deposition history on a wide continental shelf: Implications for the calculation of accumulation rates on the Great Barrier Reef. Earth Planet. Sci. Lett. 2014, 393, 146-158. [CrossRef]

77. Lough, J.M.; Cooper, T.F. New insights from coral growth band studies in an era of rapid environmental change. Earth-Sci. Rev. 2011, 108, 170-184. [CrossRef]

78. Inoue, M.; Ishikawa, D.; Miyaji, T.; Yamazaki, A.; Suzuki, A.; Yamano, H.; Kawahata, H.; Watanabe, T. Evaluation of $\mathrm{Mn}$ and Fe in coral skeletons (Porites spp.) as proxies for sediment loading and reconstruction of $50 \mathrm{yrs}$ of land use on Ishigaki Island, Japan. Coral Reefs 2014, 33, 363-373. [CrossRef]

79. Lewis, S.E.; Brodie, J.E.; McCulloch, M.T.; Mallela, J.; Jupiter, S.D.; Stuart Williams, H.; Lough, J.M.; Matson, E.G. An assessment of an environmental gradient using coral geochemical records, Whitsunday Islands, Great Barrier Reef, Australia. Mar. Pollut. Bull. 2012, 65, 306-319. [CrossRef] [PubMed]

(C) 2018 by the authors. Licensee MDPI, Basel, Switzerland. This article is an open access article distributed under the terms and conditions of the Creative Commons Attribution (CC BY) license (http://creativecommons.org/licenses/by/4.0/). 